\title{
The Prelude: A Spiritual Autobiography of William Wordsworth
}

\author{
Jamal Subhi Ismail Nafi ${ }^{1}$ \\ ${ }^{1}$ Department of English, Faculty of Arts, Al-Quds University, East Jerusalem, Palestinian Occupied Territory \\ Correspondence: Jamal Subhi Ismail Nafi', Department of English, Al-Quds University, East Jerusalem-Abu \\ Dies, P. O. Box 51000. Tel: 972-598-562-214. E-mail: jamalnafi@gmail.com
}

Received: April 15, 2015 Accepted: May 3, 2015 Online Published: May 31, 2015

doi:10.5539/ells.v5n2p146 URL: http://dx.doi.org/10.5539/ells.v5n2p146

\begin{abstract}
The aim of this paper is to examine Wordsworth's poem The Prelude in the sense of being autobiographical. The poem is considered as the longest, noblest and most fruitful illustration of the spiritual frugality of Wordsworth and a handsome anticipation of the modern concept of autobiography. The poem indicates that the autobiographer projects himself in his own literary work and renders his psyche, truthfully and realistically. Through analytical study, this paper tries to shed some light on the autobiographical elements in the poem, and to show how the poem outlines the growth of the poet's mind throughout the different stages of his life. The study discovers that The Prelude is not an autobiography in the usual sense from the holy pen of the high priest of nature. In it, we have the faithful record of his inner life and emotional experiences enabling us to have a glimpse of the innermost recesses of the poet's soul. So we may unhesitatingly call it a spiritual or poetical autobiography.
\end{abstract}

Keywords: autobiography, childhood, journey, inner, self-representation, soul, spiritual, The Prelude, Wordsworth

\section{Introduction}

It has always been a great headache for the critics and problem for readers to treat the facts and incidents mentioned by William Wordsworth in his poem The Prelude (1850), as truly biographical. Lidenberger (1964), in his study of the poem, that claims that The Prelude is the longest, noblest and most fruitful illustration of the "spiritual frugality of William Wordsworth and a handsome anticipation of the modern concept of autobiography" (p. 316).

In The Prelude Wordsworth states that the aim is the preservation of the spirit of the past "for future restoration" because the base of human greatness is childhood, which is father of manhood and, indeed, our days are bound together by the fibred piety, which the poet glances at in the remark that "feeling comes in aid of / feeling and a diversity of strength attends us / if once we have been strong" (XII. 269-271). Such feelings of childhood, the great visionary experiences, are "the spots of time to which human mind may return again and again to drink energy and new vitality, as it were, at an inexhaustible fountain." Sullivan $(2011$, p. 214, as cited in Lejeune, 2009 , p. 2) admits, all autobiographical writing has a strange relationship to its own genesis, which is no less than "the past history of its author," and which needs to be interpreted and commented on for the present or future self. Thus, and it has been suggested by the various opinions expressed above, any autobiography whatsoever is affected in one way or another by the past life of its author, and specifically by his/her childhood experience, Sullivan (Ibid) continues. This can be held true, since The Prelude reflects in one way or another the growth of its creator's mind, that is the poet himself. Throughout the poem, Wordsworth refers so often to his childhood experience, which played a major role in shaping his manhood. Thus the purpose of the poem is twofold: first, a self-examination, to fathom and find out if he was indeed a real poet and if he was fit enough for composing a great poem that will stand the test of time; second, a self-expression, enfolding the expression of an age of renewed nobility and manners. What this paper tries to achieve or determine is whether The Prelude is an autobiography in the real sense of the word.

According to Lee (2014), in The Prelude, Wordsworth seeks to establish a stable poetic identity for himself through the examination of recollected earlier selves. Books I and II of The Prelude describe the way time fractures Wordsworth's consciousness in the transitions between a range of temporalities and the way he attempts to use language to stabilize his identity. However, his "two consciousnesses"- - consciousness of myself / and of some other Being" (I. 16-17), are further problematized by the experience of the French 
Revolution.

One is reminded of Eliot's famous remark that it is the pattern which gives meaning to history and pattern is formed in a selective process of memory as reviewed by the eye of the present. The Prelude, thus, gives a pattern or meaningful organization of events and experiences, of pleasure and pain, of beauty and fear which have given significance to the whole process of living and growing, or the evolution of the present out of the past. It is in this sense that The Prelude is an autobiographical poem. "The great discovery of the $18^{\text {th }}$ century," says Poulet (1969), "is to have conceived the prime moment of consciousness as a generative not only of other moments but also a self which takes shape by and through the means of these very moments" (p. 55).

According to Pascal (1960), "Wordsworth is the first autobiographer to realize that each man constructs out of his world a unique framework of meaningful events, and that the deepest purpose of autobiography is the account of a life [emphasis added] as a projection of the real self (personality) on the world" (p. 32). These words indicate that an autobiographer projects himself in his own literary work and renders his psyche, truthfully and realistically, in words.

\section{Preparatory Poem to be Autobiographical}

It's noteworthy to quote Wordsworth's own words-relevant words from the Preface to the first edition of The Excursion in 1814:

Several years ago, when the author retired to his native mountains, with the hope of being enabled to construct a literary work that might live, it was a reasonable thing that he should take a review of his own mind and examine how far Nature and Education have qualified him for such employment. As subsidiary to this preparation, he undertook to record, in verse, the origin and progress of his own powers, as far as he was acquainted with them ... The preparatory poem is biographical, conducts the history of the author's mind to the point when he was emboldened to hope that his faculties were sufficiently matured for entering upon the arduous labor which he had proposed to himself ... (pp. 1-2).

As it has been made clear by the above quote, this "preparatory poem" is The Prelude, and the words quoted above make it crystal clear that it is to be biographical as it is "to record, in verse, the origin and progress of his own powers." It was Coleridge, 'the guardian angel of Wordsworth's poetical genius', who guided and inspired the poet to compose ". . . some philosophic song / Of truth that cherished our daily life" (I. 228-231).

This was to be his greatest poem-The Recluse (1798), "a literary work that might live." So before undertaking that arduous task of composing his great 'philosophic song' the poet began with the preparatory poem-The Prelude to serve more or less as a sort of portico to his Gothic Church The Recluse. But the irony of the situation is that his lofty venture of composing a philosophic song ended in a few hundred lines of The Excursion (1814) that was published in 1814. Meanwhile, composition of The Prelude went on and was brought to a close in 1805 with his fuller project of a poem including his experience in France and bringing his story down to 1798, when he felt his genius ripe for expression. The fact is that Wordsworth was a poet first and not a philosopher as the friend of his heart and genius liked him to be. In this regard, Darbishire (1950) has rightly said:

Wordsworth's genius could not express itself in Coleridge's terms; he could not write the true philosophical poem. Perhaps no poet can. At any rate, he was right to follow his own bent. His poetic thought sprang out of the living body of experience and could only be delivered through images, incidents and characters which belonged to the life of man and nature as he knew it: the autobiographic form of The Prelude fitted his genius (pp. 12-13).

The above words suggest that the poem is to be taken literally as an autobiography in the real sense of the word, but not all aubiographies reveal much about the lives of their creators. This raises the question of how much of the poet's self is revealed in the poem.

\subsection{Not an Autobiography in the Usual Sense}

At the very outset, it must be clear to us that The Prelude is not an autobiography in the usual sense. Of course in the preface to The Excursion, the poet has told us that the preparatory poem is "biographical." So, it may be biographical, but still not so in a straightforward and chronological way. Here events never follow each other in the order in which they happened. The poet discarded the simply chronological arrangement in favor of one which would just stress on the essential importance of certain experiences and states of mind. To the poet, the subjective aspect is much more important that the objective aspect of the poem. So we must be clear in our mind that the subject is not "My Life," but "The Making of a Poet," although Wordsworth has used the phrase "the story of my life" (639) at the end of Book I. Prof. Garrod (1923) has rightly said that: 
the purpose of 'The Prelude' may, indeed, be said to be to search out and seize and hold, among the many seemingly alien and incongruous images of self cast up by reflection, the image of the poet's true being, of his slowly self-realizing individuality, of that in him in virtue of which he is a 'dedicated spirit.' (pp. 78-79).

\subsection{Poetic Inspiration on His Way to Racedown}

Thus in the very "Preamble" of Book I, we can, to a great extent, guess the shape of things to come. An unexpected legacy (900) of a friend, Raislly Calvert, freed Wordsworth from pecuniary troubles. "Escaped from the vast city" (p. 7), the poet is on his way to Racedown from Bristol. And with "the sweet breath of heaven" (I. 33) he feels "a correspondent breeze" (Ibid) to inspire his soul with poetic zeal. And very soon he feels himself to be "a renovated spirit singled out for holy services" (I. 53), and:

... a higher power

Than Fancy gave assurance of some work

Of glory there forthwith to be begun,

Perhaps too there performed. (I. 77-79)

Well, the "work of glory" was never begun or performed there; instead we got The Prelude, the finest fruit of Wordsworth's great creative period; a poem which outlived and gave fame to its author.

\subsection{Record of Inner Life}

So, in The Prelude we get a record-a record of that inner life out of which Wordsworth's poetry grew. It's the full intense life of childhood and youth that the poet tried to capture and record. So in Books I and II we have Wordsworth's childhood and boyhood experiences amid the lovely natural surroundings. Herein lies the greater significance of these two books. And, from the poet, we get that his poetic life began, as it were, on the banks of the Derwent when he was just a suckling babe. When he found himself "Baffled and plagued by a mind that every hour / Turns recreant to her task. (I. 257-258). He appeals to the river Derwent- “... Was it for this / That one of the fairest of all rivers loved, / To blend his murmurs with my nurse's song. (I. 269-271).

And when the boy Wordsworth was transplanted to that "beloved Vale" of Hawkshead in Esthwaite it began, to some extent, consciously. The benign influence of Nature to shape and mould his character and poetic personality had already started. "Fair seed time had my soul, and I grew up / Fostered alike by beauty and by fear" (I. 301-302). Here we see how nature was to the poet and how much it affected his soul and being. Nature for Wordsworth was more than a nurse; it was his mother, guide, and his whole being.

\section{Awakening of Poet's Love of Nature}

But the awakening of the poet's love of nature is the most significant element in his early education. At the early stage it was just a normal and healthy boy's love for open air sports and pastimes amidst lovely surroundings of nature. So in Books I and II we get an unforgettable recreation of his childhood involvement in physical activities and the joys and fears which were their consequence. In the first two Books Wordsworth tells us of various exciting activities in which he used to take part with all joy and zeal. In the first Book we have the following - "bathing, bird-snaring, bird-nesting, and expedition in a stolen boat, skating, fishing, kite-sailing, noughts,-and-crosses and cards." In the second Book, also we find they still "ran a boisterous course" and their favorite pastimes were boat-races, boating excursions on the lake, walking tours and riding on horses "through rough and smooth."

\subsection{Emotions of Pleasure and Pain}

The first Book is studded with several impressive incidents showing us the means by which Nature affects her discipline on young Wordsworth by evoking the emotions of pleasure and fear. Thus on a hot summer day, the child would have pure animal pleasure by bathing or basking:

Oh, many a time have it a five years' child,

In a small mill-race severed from his stream.

Made one long bathing of a summer's day;

Basked in the sun, and plunged and basked again

Alternate, all a summer's day... (I. 288-292)

And then during his night adventure with the stolen boat, we find how he was overwhelmed with an alarming sense of panic and fright by the awful sight of a towering peak when the grim shape: 
Towered up between me and the stars, and still,

For so it seemed, with purpose of its own

And measured motion like a living thing,

Strode after me. (I. 382-385)

So the beautiful and sublime objects and images of nature with their benign influence ennobled his emotions and moulded his mind, and the poet tells us:

... purifying thus

The elements of feeling and of thought,

And sanctifying, by such discipline,

Both pain and fear, until we recognize

A grandeur in the beatings of the heart. (I. 410-414)

\subsection{Three Stages of Poet's Love of Nature}

Another very significant aspect that strikes us in The Prelude, especially in the first two Books, is that in it the poet has traced the three stages of his love of nature. We are able to mark three phases of development. In the first phase, as a child we find the poet deriving simple animal or sensuous delight in Nature. In the second stage he could have more mystical and spiritual pleasure from his deep and close contact with Nature. And finally, we find the love of Nature leading to the love of man, and this change brings about a calmer and sober attitude. Again in Book II, we are aware of the other three phases in the process by which the transcendental or mystical relationship is established between Nature and the poet.

\section{Wordsworth Writes of Himself}

According to Dr. Samuel Johnson, “Every man's life is best written by himself” (qtd. in Tlueblood, 1974, p. 1). Wordsworth took the hint and produced what Legouis (1965) describes "the unique autobiographical poem" (p. 32). If these views are to be held true, then Wordsworth's 'The Prelude' is the greatest autobiography in verse in English. Wordsworth calls it "A poem on my own earlier life" (Letters 3). In the closing lines of Book I, the poet says that it would form a part of the story of his life which he aspired to record in the following books. It is again in Book I that Wordsworth tells Coleridge that the poem would help the latter in knowing "how the heart was framed of him thou lovest" (Wordsworth, I., pp. 627-628).

Wordsworth admitted indeed that it was a thing unprecedented in literary history that a man should talk so much about himself. "It is not self-conceit," (Wordsworth, Letters, 1993) he wrote in a letter to George Beaumont in 1805: that induced me to do this, but real humility. I began the work because I was unprepared to treat any more arduous subject, and diffident of my own powers. Here at least, I hoped that to a certain degree I should be sure of succeeding, as I had nothing to do but describe what I had felt and thought; therefore could not easily be bewildered (p. 2).

The above quote suggests the tone and feelings of the poet before he composed the poem. Wordsworth was to a certain degree sure of his success and though that his achievement would be great and would make him famous.

\subsection{Wordsworth's Poetry and His Personal Experience}

The connection between Wordsworth's poetry and his personal experience is of the closest kind, and he undertook the writing of The Prelude in a mood of self-examination. The poet aspired to create a literary work that might live; and he considered it right to examine his powers for such a task before he actually undertook it. The result was The Prelude. The poem is thus Wordsworth's assessment of his own powers and a record of those influences that moulded him. And in this psychological account of the growth of his own mind, and of the most significant of the influences that shaped it, he has done the biographer's work once and for all.

According to Herford (2004), his boyhood in: the beloved vale is the most memorable of all poetic boyhoods and the first two Books of 'The Prelude' reach the highest level of spiritual autobiography and touch now and then the highest levels of English poetry by simply recording with perfect fidelity whatever in it bore upon the growth of his own mind (p. 272).

His account of the act of stealth and troubled pleasure about the stolen boat ride in Book I is heart-thrilling and shows the poet in his boyhood years. The concluding lines are worth quoting. They move the readers because they record an everlasting impression the sight of a seemingly moving mountain created on the poet: 
... but after I had seen

That spectacle, for many days, my brain

Worked with a dim and undetermined sense

Of unknown modes of being; o'er my thoughts

There hung a darkness, call it solitude

Or blank desertion. No familiar shapes

Remained, no pleasant images of trees,

Of sea or sky, no colours of green fields;

But huge and mighty forms, that do not live

Like living men, moved slowly through the mind

By day, and were a trouble to my dreams. (I. 390-400)

Such experiences, as the poet says, became a part of his very being and make-up.

\subsection{Nature Formative Influence: The Growth of the Poet's Mind}

The theme of the influence of Nature on man is the noblest part of Wordsworth's teaching in poetry, and that is the theme of The Prelude, Book I. This Book deals with his childhood and school time. The poet has graphically and sympathetically described his experiences of boyhood amidst nature surroundings. The poet starts the poem with describing an infant's world, progressing through youth and including such scenes as a girl on a hill and sympathy for a blind beggar, as stated by Miall (1992, p. 1). And it can be deduced that Wordsworth has received the education of nature, which was his best teacher. Addressing Derwent, the poet says:

... didst thou,

O Derwent! winding among grassy holms

Where I was looking on, a babe in arms,

Make ceaseless music that composed my thoughts

To more than infant softness, giving me

Amid the fretful dwellings of mankind

A foretaste, a dim earnest, of the calm

That Nature breathes among the hills and groves. (I. 274-281)

Wordsworth in his "fair seed time" had wandered in the company of nature, seen her summer beauties and wintry colds, and experienced her spring spells and autumn mellowness: he had become, as it were, a part of Nature. In the same book, he says:

Through half the night,

Scudding away from snare to snare, I plied

That anxious visitation;---moon and stars

Were shining o'er my head. I was alone,

And seemed to be a trouble to the peace

That dwelt among them. (312-317)

Compare the above passage with the following passage from Book V:

There was a Boy: ye knew him well, ye cliffs

And islands of Winander! - many a time

At evening, when the earliest stars began

To move along the edges of the hills,

Rising or setting, would he stand alone

Beneath the trees or by the glimmering lake. (364-69).

Here is the poet's reference to his boyhood; that boy grew to be a youth: he could not shake off these influences. 
"Mind in infancy is like body in the embryo." Wordsworth has described the formative influence of Nature on the unfolding mind of child. This unroofed school of nature attracted him more than the discipline of the classics, and he learnt more eagerly from flowers and hills, and stars than from his books. His unbound love and admiration for nature is the outcome of the unceasing influences he received from Nature during his early years, when he imagined nature speaking to him, and as if it were his fellow friend. Wordsworth's firm belief is that nature took keen interest in the farming of the human mind.

\section{The Prelude: A Key to Wordsworth's Poetry}

Thus The Prelude is not to be viewed only as a poem of Wordsworth's life; it is a key supplied by the poet himself to unlock the door leading to his poetic chamber. With the help of this long, personal poem, a reader can understand and interpret the rest of Wordsworth's poetry more intelligently. It is a guide book for understanding comprehensively the unbroken relationship between human life and nature, without which life to Wordsworth was no life. His childhood became responsible for making Wordsworth a great poet of nature. The Prelude is the essential living document for the interpretation of Wordsworth's life and poetry.

\subsection{Nature and Man in Wordsworth}

"Wordsworth had his passion for Nature fixed in his blood," observed De Quincy (1970). "It was a necessity of his being like that of the mulberry leaf to the silkworm, and through his commerce with Nature did he love and breathe." (p. 22). Hence it was from the truth of his love that his knowledge grew. If Wordsworth had a favorite subject, it was Nature, and when he treated of man it was essentially in relation to Nature. It was the love of Nature that led him to the love of man. In the words of Pater (2001), "Wordsworth approached the spectacle of human life through Nature. When he thought of man, it was as in the presence and under the influence of effective natural objects and linked to them by many associations" (p. 12). These words indicate how Nature and Wordsworth used to interact faithfully and innocently with each other. And the solace and calmness the poet received from Nature positively affected his later relationships with human beings.

This theme of the influence of Nature on man is the noblest part of Wordsworth's teaching in poetry. Nature is the best educator, and she is ever interested in Man and tries to impress human mind from its earliest dawn. The following words from Book I can clearly and faithfully illustrate this point:

I believe

That Nature, often times, when she would frame

A favour'd Being, from his earliest dawn

Of infancy doth open up the clouds

As at the touch of lightening, seeking him

With great visitation. (362-367).

If we consider the above quotation carefully, we will realize how nature made the poet love human kind in general, and how the poet found solace when his soul was troubled.

Three things must impress even the casual reader of The Prelude: first, Wordsworth's love to be alone, he is never lonely with nature. Second, like every other child, who spends much time in the woods and fields, he feels the presence of some living spirit, real though unseen, and companionable though silent. Finally, His early impressions make him what he, later on, becomes: "The child is the father of man" (Wordsworth, My Heart Leaps Up, p. 7)

\section{The Prelude and Wordsworth's Poetic Genius}

The Prelude Book I offers an instructive deep in the workshop of the poet. Through Wordsworth's own mouth, we hear of his mind's desire to "gladly grapple with some noble theme," and how the mind finding impediments "from day to day renewed" (I. 131) was content "to yield up those lofty hopes" (I. 133). A touching reference is made to his "unmanageable thoughts" (I. 139) .We are informed that he possessed all that was "needful to build up a poet's praise" (I. 157). He had the "first great gift: the vital soul," "general truth. Nor was he naked in forms, images and numerous other aids which are "won perhaps with toil." The poet was invaded by doubts. Had he the strength to assume so awful a burden? Would it not be wiser to await those "mellower years" that "bring a riper mind." Are his misgivings valid, or are they mere timidity and laziness, a subtle form of selfishness cloaked in humility and modest awe?

But from this awful burthen I full soon

Take refuge, and beguile myself with truth 
That mellower years will bring a riper mind

And clearer insight. Thus from day to day

I live, a mockery of the brotherhood

Of vice and virtue, with no skill to part

Vague longing that is bred by want of power

From paramount impulse not to be withstood

A timorous capacity from prudence;

From circumspection, infinite delay.

Humility and modest awe themselves

Betray me, serving often to cloak

To a more subtle selfishness, that now

Doth Lock my functions up in a blank reserve

Now dupes me by an over-anxious eye

That with a false activity beats off

Simplicity and self presented truth....

... for either still I find

Some imperfection in the chosen theme,

Or see of absolute accomplishment

Much wanting, so much wanting in myself.

That I recoil and droop. (I. 234-255)

We find poems in their finished form, but Wordsworth has described what pains a poet has to undergo and what periods of uncertainties he has to go through. Thus "poetic experience itself becomes the subject of The Prelude, the "Presiding genius" of the poem.

Besides the great influence that Nature exercised over the poet's mind, we are told in Book V of Wordsworth's debt to literature and learning. It is true that the Book does not deal in detail with the books on which Wordsworth had fed in his early years. But Arabian Nights (1706), Spenser's The Faerie Queene (1590) and Othello (1603) are mentioned as his favorite books. Influence of Dorothy and Coleridge on him should not be lost sight of.

\section{Two Versions of The Prelude as Indications of the Growth of the Poet's Mind}

A comparison of the 1805 and 1850 texts gives us further information about the growth of the poet's mind between the two dates. The critics are not agreed as to which of the two editions is better than the other; but the changes made in the original text indicate a change in Wordsworth's mental powers: (1) Bald simplicity (of 1805) gives place to more decorative, more conventionally literary form. (2) Rough and crude expression is smoothed and clarified; faults of ambiguity and loose repetition are carefully amended. (3) "The most vital changes lie deeper still," says Darbishire (1950, p. 7), "they touch what we should now call the psychology of the poem" (Ibid). In the early The Prelude Wordsworth told of the inner workings of his mind as nakedly and truthfully as he could. The changes most to be deplored in his later text are those which overlay and obscure that native expression; they often mar the poetry; more often disguise the truth. Thus in the former version the feeling is more genuine and spontaneous, less cautious; in the latter the style is generally speaking stronger and more finished. The first reveals personality more genuinely, the second reveals him as an artist.

It is generally when an autobiography deals with the author's childhood and first beginning that he most often succeeds in reaching the hearts of many of his readers. Wordsworth's life which, to many of his readers, appeared to be a monotonous affair, comes out in The Prelude as a life, of "pure energy from the beginning, wakeful, alert, self-willed" (Ker, 1903, p. 11). It is true that the poem is a story of the poet's own life. But its story, by itself, is not so important. The poem is the study of the origin of Wordsworth's poetic power: The Prelude is less a narrative than a study of origin, less the history of man than the philosophy of mind. In order to appraise the poetic genius of Wordsworth, let one read The Prelude in which the sources of his poetic inspiration are to be found. 


\section{And in the End All Gratulant}

Thus after tracing the growth of the poet's mind through various stages of his life with all ups and downs, with its storms and stress, the optimistic mind of the poet feels elated as this history is brought to a close. The poet is no longer a prey to his doubts and diffidence; he has fully regained his confidence in his own powers as a poet for "building up a work that shall endure." Hence he feels himself raised as if a bird on wings and his poems seems to him like the enchanting song of a lark:

$\ldots$ and hence this song, which like a lark

I have protracted, in the unwearied Heavens

Singing, and often with more plaintive voice

Attempted to the sorrows of the earth;

Yet centering all in love, and in the end

All gratulent if rightly understood. (XIV. 382-387).

Cazamian (1927) has noted that the opening lines of Book II of The Prelude force the readers to notice "A note of personal tenderness, an almost elegiac inclination to evoke the memories of his own childhood, make 'The Prelude' the most admirable record of a soul's progress towards the full possession of self, which is implied in the apostolate of a poetic calling" (p. 202).

\section{Conclusion}

Thus in The Prelude we find the poet first trying to recapture and record the full intense life which he lived through his senses as a child and youth. Wordsworth had the extraordinary power to "live intensely in the past, he could revive and recreate; and it is a chief part of his purpose in 'The Prelude' to recall and quicken into permanent life those pregnant moments. For they were, he well knew, the making of him as a poet" (Moorman, 1957, p. 22).

We may now conclude without any reservation that The Prelude is not an autobiography in the usual sense from the holy pen of the "high priest of nature." Although it may, to a fairly good extent, be a source of information about the poet and a guide to the significant events in Wordsworth's early life. In it we have the faithful record of his inner life and emotional experiences enabling us to have a glimpse of the innermost recesses of the poet's soul. So we may unhesitatingly call it a spiritual or poetical autobiography. Prof. Read (2006) has justly observed: “"The Prelude,' undoubtedly places before us Wordsworth-the revolutionary; Wordsworth-the man; Wordsworth-the poet; and finally, Wordsworth-the high priest of nature" (p. 25). This quote suggests that the poem reveals before us the great poet of nature, and Wordsworth as man and child, whose soul has truthfully been laid naked. Hence we may without the least hesitation discard the idea of treating The Prelude as mere autobiography and accept it as a great poetically autobiographical poem without any reservation.

\section{References}

Cazamian, L. (1927). A history of English literature: Modern times (1660-1914). Trans. By W. D. Maclnnes \& Helen Douglas- Irvine. NY: Macmillan.

Darbishire, H. (1950). The poet Wordsworth. Oxford: Clarendon Press.

De Quincey, T. (1970). Recollections of the lakes and the lake poets (David Wright ed.). New York: Penguin Books.

Garrod, W. H. (1923). Wordsworth: Lectures and essays. Oxford: Oxford University Press.

Herford, C. H. (2004). The age of Wordsworth. Whitefish, Montana: Kissinger Publishing, LLC.

Ker, W. P. (1903). William Wordsworth. In Robert Chambers (Ed.), Cyclopedia of English Literature (2nd ed., Vol. 3). London: Chambers.

Lee, C. J. (2015). Between speech and silence in Wordsworth's The Prelude-transformation of self in text. EURAMERICA, 44(2), 193-238. Academia Sinica. Retrieved from http://euramerica.org Between Retrieved from $\mathrm{http}: / /$ go.galegroup.com/ps/i.do?

Legouis, E. (1965). The early life of William Wordsworth. 1770-1798. A study of The Prelude. Trans. by J.W. Mathews with a prefatory note by Leslie Stephen. New York, NY: Russel \& Russel Inc.

Lindenberger, H. (1964). On Wordsworth's 'Prelude' (p. 316). Princeton, N. J.: Princeton University Press.

Miall, D. S. (Summer 1992). Wordsworth and 'The Prelude': the problematics of feeling. Studies in Romanticism, 
31(2), 233-236. http://dx.doi.org/10.2307/25600953

Moorman, M. (1957). William Wordsworth, a biography: The early years, 1770-1803. Oxford: Oxford University Press.

Pascal, R. (1960). Design and truth in autobiography. Cambridge, Massachusetts: Harvard University Press.

Pater, W. (2001). The aesthetic moment (pp. 1-226). David H. Wilson. Trans. Cambridge: Cambridge University.

Poulet, G. (1969). Phenomenology of Reading. New Literary History, 1(1). http://dx.doi.org/10.2307/468372

Read, H. (2006). Recritiquing Wordsworth. Pradip Kumar Patra \& Amar Nath Prasad (Eds.). India: Sarup \& Sons.

Sullivan, H. (Spring 2011). Autobiography and the problem of finish. Biography, 34(2), 298-325. http://dx.doi.org/10.1353/bio.2011.0029

Trueblood, E. (1974). While it is day. New York: Harper \& Row.

Wordsworth, W. (1814). The Excursion. Sally Bushell \& James A. Bulter et al. (Eds.). Ithaca: Cornell University Press, 2007.

Wordsworth, W. (1850). The Prelude; or Growth of a Poet's Mind. New York: Appleton.

Wordsworth, W. (1991). The thirteen-book of The Prelude. M. L. Reed (Ed.). Ithaca, NY: Cornell University Press.

Wordsworth, W. (1993). The letters of William and Dorothy Wordsworth. In A. G. Hill (Ed.), The New Leader: A Supplement of New Letters. Oxford: Clarendon Press.

\section{Copyrights}

Copyright for this article is retained by the author(s), with first publication rights granted to the journal.

This is an open-access article distributed under the terms and conditions of the Creative Commons Attribution license (http://creativecommons.org/licenses/by/3.0/). 